\title{
A New Species of the Gobiidae Family in Transylvania Waters: Racer Goby (Babka gymnotrachelus, Kessler 1857)
}

\author{
Daniel Ioan COCAN ${ }^{1}$, Vasile OȚEL ${ }^{2}$, Călin LAȚIU ${ }^{1}$, Tudor PĂPUC ${ }^{1}$, Vioara MIREŞAN ${ }^{*}$ \\ ${ }^{1}$ Faculty of Animal Science and Biotechnologies, University of Agricultural Sciences and Veterinary \\ Medicine Cluj-Napoca, 3-5 Mănăștur Street, 400372, Cluj-Napoca, Romania \\ ${ }^{2}$ Danube Delta National Institute for Research and Development - Tulcea. 165 Babadag St., Tulcea, \\ 820112, Romania \\ * corresponding author: vmiresan@yahoo.com
}

Bulletin UASVM Animal Science and Biotechnologies 73(2)/ 2016

Print ISSN 1843-5262; Electronic ISSN 1843-536X

DOI:10.15835/buasvmcn-asb: 12221

\begin{abstract}
The racer goby (Babka gymnotrachelus) is one of the well represented Ponto-Caspian goby species in most Danube Delta Biosphere Reserve lakes and channels, including Razim-Sinoe lagoon complex and lower sector of the Danube. Also, the presence of this species is notedin some lakes near Bucharest. The presence of this species in Transylvania has not been reported until now,during ichthyologic investigations from 2015-2016, seven specimens from Someș River and some of its tributaries, were captured:one specimen was caught in a channel adjacent to Țaga Mare Lake, one specimen was caught in Someșul Mare River (Mica village, Cluj County), two specimens were captured from the confluence of the Someșul Mic River and FizeșRiver.The sixth specimen were captured from Fizeş River (Fizeşu Gherlii village, Cluj County) and the last one was also caught from the Fizeş River (Sântioana village, Cluj County). It is possible that the species migrated in Someș Catchment from the Hungarian Danube sector, by the tributaries of Tisa River, or it might have originated from stocking material used in fish farms in Transylvania. The somatic, gravimetric and meristic measurements of the collected specimens were taken in the Acquaculture and Acquatic Organisms Phisyology laboratories from the University of Agricultural Sciences and Veterinary Medicine Cluj-Napoca and correspond with those mentioned in the published literature regarding this species.
\end{abstract}

Keywords: Babka gymnotrachelus, new species, Transylvanian waters

\section{INTRODUCTION}

The racer goby is a Ponto-Caspian species, with a native range consisting in the catchments of the rivers that flow in the Black and Azov Seas, the Marmara Sea, the north and center of the Caspian Sea.In the last decades, the species shows an expansion towards western and northern Europe (Miller, 2003). In Romania, its current presence is limited to the south-east: the lakes near Bucharest, the lakes and channels in the Danube Delta, the shallow waters of the Danube, the coastal lakes. It prefers stagnant freshwaters, with a muddy substrate. Sexual maturity occurs after the second year of life, at an approximate length of 9-11 cm. Reproduction occurs in April - June, when the female lays about 1.000 eggs in a nest made from vegetal detritus, gravel or shells. The males guard the nest. The feed is represented by a large scale of benthonic invertebrates and occasionally fish eggs and juveniles (Oțel, 2007).

The species was reported lately in some European waters. It spread and adapted to new territories as a consequence of human displacement and transportation, climate change, 
water quality improvement, hydraulic engineering and hydropower constructions(e.g.: ripraps, channel constructions). Some major causes are river and sea transport by ships and the great adaptivepotential of this species.These are among the elements that mostly affect the invasive spread of Ponto-Caspian gobies.

Discrepant or unsubstantiated information regarding the presence ofBabka gymnotrachelus species in some territories (Roche et al., 2013) and mistakento different species occasionally occurs in scientific literature. Regarding the westward migration dynamics, the species was found in Yugoslavia in 1991 (Hegedis et al., 1991). Its presence is reported in the Baltic Sea basin in 1995 (Gollasch, 2006). Two specimens were captured from the Danube in Austria, in 1999 (Anhelt et al., 2001). The first racer goby specimen was caught in the same year, in October, from a Danube armlet near Bratislava (Kautman et al., 2001). In later studies conducted on the Slovak Danube, the species was no longer found and it was presumed that few local populations exist, thus the establishment process of this species in the middle Danube basin is at an initial phase (Jurajda et al., 2005). It appeared in Vistula River in Poland, in 2001 (Kostrzewa and Grabowski, 2001), the hypothesis according to which the species reaches the Baltic Sea basin from the Black Sea basin by the Bug-Pripyat Canal, which connects the two basins, was launched.

Two specimens were captured in the Danube, in Hungary, in September, 2004 (Guti, 2006), its presence being later confirmed by other authors (Weiperth et al., 2013). Years later, the species invaded a few Danube tributaries from Bulgaria (Zarev et al., 2013), like Yantra River (Vassilev et al., 2008). The racer goby is reported in the German Danube in September of 2011, near the town of Regensburg (Haertl et al., 2012). Furthermore, the species was recorded in the same year in the Rhine (Borcherding et al., 2011), but further analysis concludes that the sampled specimens were erroneously identified, being in fact either monkey gobies, either hybrids.The species shows up remotely in Austria and Germany, neighboring urban centers and industrial harbors (Roche et al., 2013), hence being presumed that it was accidentally transported along with ballast water in ship tanks. Additionally, the studies on the German and Austrian Danube course were conducted on the navigation channel, but the species prefers shallow, muddy waters, which was why it was found only in some areas (Haertl et al., 2012). There are two genetically distinct populations in Poland, a local one and an invasive one (Grabowski et al., 2016).

Bij de Vaate et al., (2002) identified three potential main invasion corridors, which developed as a result of canal constructing: the north corridor includes the Volga River, Beloye, Onega and Ladoga Lakes, Neva River and then the Baltic Sea; the central corridor consists in the Dnieper, Vistula, Notec, Warta, Oder, Elba rivers, the Rhine and then the North Sea; the southern corridor includes the Danube, the Rhine and the North Sea. It is presumed that these corridors have significantly influenced the range expansion of gobies in Europe (Kostrzewa and Grabowski, 2003).

\section{MATERIALS AND METHODS}

Studies regarding the presence and distribution of Babka gymnotrachelus in the Someş Catchment (Fig. 1) were conducted from August 2015 to July 2016. Overall, seven specimens were caught from five sampling sites (Fig. 1, Tab. 1), an adult specimen and six juvenile specimens. They were preserved in formalin solution until further analysis.The collection method used was angling, using housefly maggots (Musca domestica) and red worms (Eisenia foetida) as bait. The first racer goby was caught in an adjacent channel to Țaga Mare Lake, and the second one was caught in Someşul Mare River, near Mica village (Cluj County). The following sampling points were selected between the two localities. The biometric and gravimetric measurements were taken in the Acquaculture and Acquatic Organisms Phisyology laboratories from the University of Agricultural Sciences and Veterinary Medicine Cluj-Napoca. Forty-seven phenotypic characters and six meristic characters were determined (Fig. 2, Tab. 2 and Tab. 3). The measurements were taken using an electronic scale and an electronic caliper, being later analyzed with the Piximetre 5.9. software. The digital photographs were taken with a Nikon P530 Coolpix camera and edited in Paint.net 4.0.5.

Several measurements were taken in order to make a phenotypic depiction of the captured racer goby specimens, focusing on characters regarding the morphology of the head, body and fins. The 


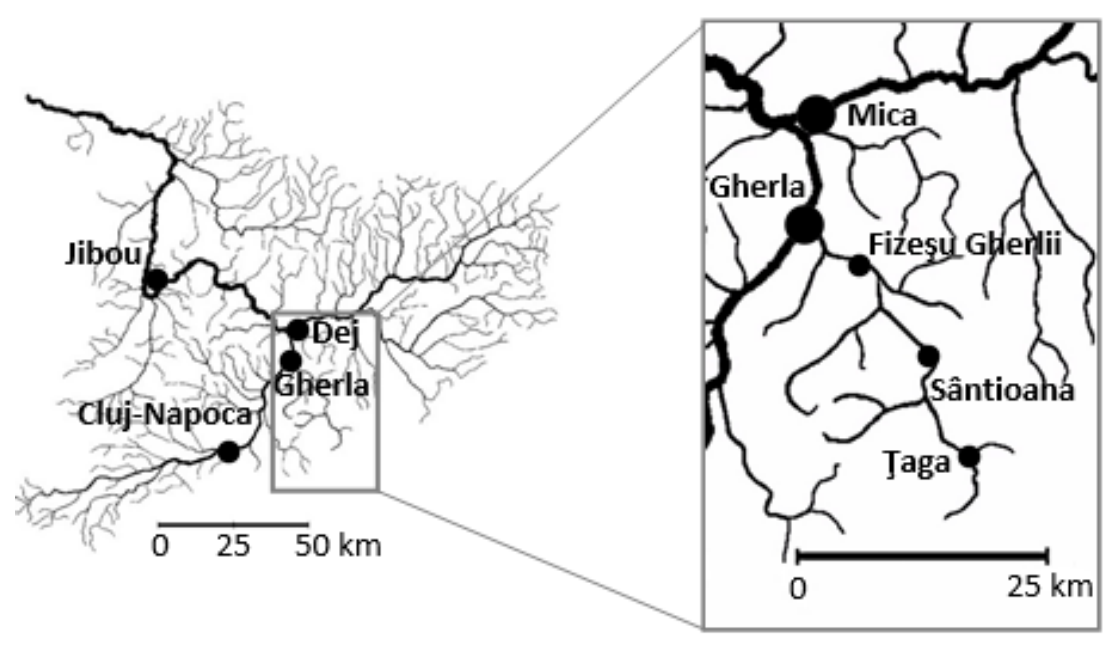

Fig. 1. Someş Catchment (left) andracer goby (Babka gymnotrachelus) sampling sites (right)

Tab.1.Racer goby (Babka gymnotrachelus) sampling points and GPS coordinates

\begin{tabular}{|c|c|c|c|c|}
\hline No. & Location & Date of sampling & $\begin{array}{c}\text { Specimens } \\
\text { caught }\end{array}$ & GPS coordinates \\
\hline 1 & Țaga (Țaga Mare Lake) & August 2015 & 1 & $\mathrm{~N} 46^{\circ} 93^{\prime} 81^{\prime \prime}-\mathrm{E} 24^{\circ} 06^{\prime} 86^{\prime \prime}$ \\
\hline 2 & Mica (Someş river) & September 2015 & 1 & $\mathrm{~N} 47^{\circ} 15^{\prime} 13^{\prime \prime}-\mathrm{E} 23^{\circ} 91^{\prime} 93^{\prime \prime}$ \\
\hline 3 & Gherla (Someş-Fizeș confluence) & July 2016 & 2 & 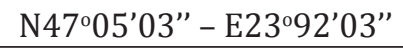 \\
\hline 4 & Fizeșu Gherlii (Fizeş river) & July 2016 & 2 & $\mathrm{~N} 47^{\circ} 02^{\prime} 15^{\prime \prime}-\mathrm{E} 23^{\circ} 97^{\prime} 30^{\prime \prime}$ \\
\hline 5 & Sântioana (Fizeș River) & July2016 & 1 & $\mathrm{~N} 46^{\circ} 96^{\prime} 33^{\prime \prime}-\mathrm{E} 24^{\circ} 01^{\prime} 90^{\prime \prime}$ \\
\hline
\end{tabular}

following head measurements were determined: inter-orbital distance (I-oD) [1], nostrils intervals (N1-I, N2-I) [2, 3], commissure interval (CI) [4], head length (HL) [5], head height $(\mathrm{HH})$ [6], eye diameter (ED) [7], pre-orbital distance (Pre-o-D) [8], post-orbital distance (Post-o-D) [12], upper jaw length (UjL) [9], lower jaw length (LjL) [10] and snout length (SnL) [11].

The next phenotypic character values were determined concerning the body: body weight (BW), total length (TL) [13], standard length (SL) [14], maximum height $(\mathrm{H})$ [15], minimum height (h) [16], great perimeter (GP), small perimeter (SP) and body depth (BD). The last characters, as well as the body weight are not represented graphically.

\section{RESULTS AND DISCUSSION}

The obtained values regarding the somatic measurements of racer goby captured in

Transylvania waters are presented in table 2 . As it can be seen, the specimen caught inSomeşul Mare River, downstream of Mica Dam, is an adult male (male - highlighting the genital papilla), having a length approaching the maximum values (Bănărescu, 1964) and a melanic body colouring specific to the reproductive period (Oțel, 2007). The other six specimens had shorter lengths, with their age evaluated at one year. Also, the adult specimen was captured in areas with high water flow velocities, with a rocky substrate, whereas the smaller specimens were caught in sections with lower flow velocities, with shallow water and muddy substrate.

According to published literature (Bănărescu, 1964) the maximum height $(\mathrm{H})$ of the racer goby is equal to $17-22.5 \%$ of the standard length (SL). In the case of the adult male specimen captured at Mica, this ratio is $17.67 \%$, while the ratio for the young specimens is between $17.68-20.45 \%$. Also, the ratio between the body depth (BD) and the maximum height $(\mathrm{H})$ must be placed between $75-96 \%$. Our results confirm this ratio, the mean being equal to $81.80 \%(74.15 \%-89.52 \%)$. The head length (HL) proportionis higher compared to the standard length (SL), the literature mentioning 

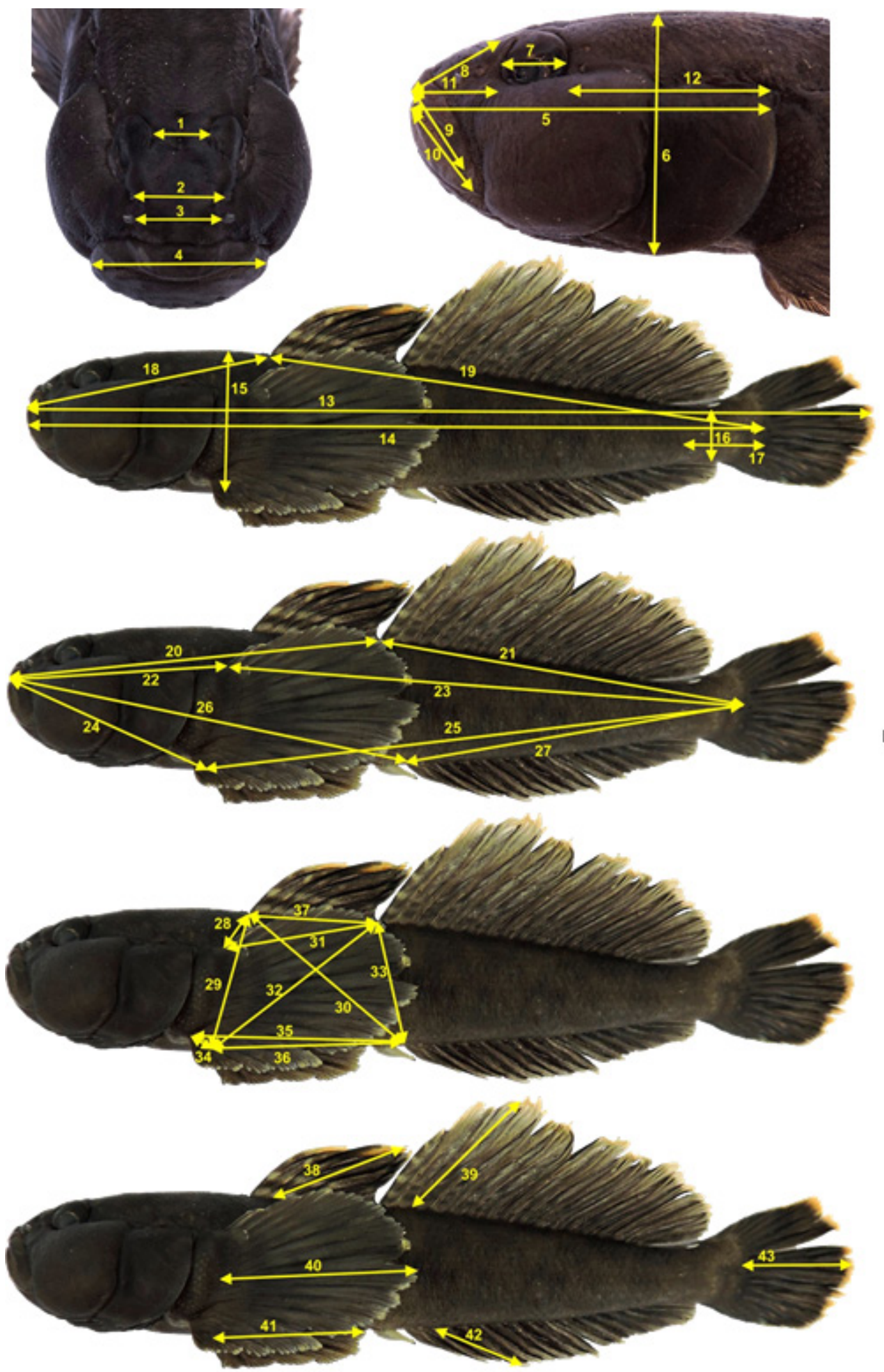

Fig. 2. Graphic representation of the measurements of the racer goby (Babka gymnotrachelus) 
Tab. 2.Phenotypic character values determined for the specimens of racer goby(Babka gymnotrachelus) sampled in the SomeşCatchment

\begin{tabular}{|c|c|c|c|c|c|c|c|c|}
\hline \multirow{2}{*}{ Character } & \multirow{2}{*}{ MU } & \multirow{2}{*}{ Țaga } & \multirow{2}{*}{ Mica } & \multicolumn{2}{|c|}{ Gherla } & \multicolumn{2}{|c|}{ Fizeșu Gherlii } & \multirow{2}{*}{ Sântioana } \\
\hline & & & & 1 & 2 & 1 & 2 & \\
\hline Body weight (BW) & g & 3.00 & 16.00 & 3.00 & 2.00 & 3.00 & 3.00 & 2.00 \\
\hline Total length (TL) & $\mathrm{cm}$ & 6.93 & 11.76 & 6.65 & 6.22 & 5.87 & 5.79 & 5.30 \\
\hline Standard length (SL) & $\mathrm{cm}$ & 5.70 & 10.07 & 5.65 & 5.32 & 4.92 & 4.89 & 4.44 \\
\hline Great perimeter (GP) & $\mathrm{cm}$ & 3.31 & 5.19 & 3.46 & 3.26 & 2.95 & 3.08 & 2.32 \\
\hline Small perimeter (SP) & $\mathrm{cm}$ & 1.15 & 2.22 & 1.55 & 1.30 & 1.27 & 1.38 & 1.12 \\
\hline Maximum height $(\mathrm{H})$ & $\mathrm{cm}$ & 1.05 & 1.78 & 1.10 & 0.97 & 0.87 & 1.00 & 0.88 \\
\hline Minimum height $(\mathrm{h})$ & $\mathrm{cm}$ & 0.47 & 0.73 & 0.47 & 0.35 & 0.41 & 0.42 & 0.39 \\
\hline Body depth (BD) & $\mathrm{cm}$ & 0.94 & 1.32 & 0.87 & 0.80 & 0.72 & 0.76 & 0.78 \\
\hline Caudal peduncle length (CpL) & $\mathrm{cm}$ & 0.72 & 1.24 & 0.69 & 0.62 & 0.53 & 0.53 & 0.48 \\
\hline Head length (HL) & $\mathrm{cm}$ & 1.91 & 2.40 & 1.56 & 1.51 & 1.54 & 1.53 & 1.19 \\
\hline Head height $(\mathrm{HH})$ & $\mathrm{cm}$ & 1.02 & 1.75 & 1.09 & 0.99 & 0.98 & 0.99 & 0.91 \\
\hline Snout length (SnL) & $\mathrm{cm}$ & 0.47 & 0.80 & 0.42 & 0.41 & 0.38 & 0.35 & 0.36 \\
\hline Eye diameter (ED) & $\mathrm{cm}$ & 0.37 & 0.36 & 0.30 & 0.27 & 0.30 & 0.30 & 0.28 \\
\hline Upper jaw length (UjL) & $\mathrm{cm}$ & 0.51 & 0.76 & 0.41 & 0.46 & 0.42 & 0.42 & 0.35 \\
\hline Lower jaw length (LjL) & $\mathrm{cm}$ & 0.54 & 0.61 & 0.39 & 0.43 & 0.40 & 0.38 & 0.25 \\
\hline Inter-orbital distance (I-oD) & $\mathrm{cm}$ & 0.19 & 0.50 & 0.24 & 0.21 & 0.14 & 0.15 & 0.10 \\
\hline Pre-orbital distance (Pre-o-D) & $\mathrm{cm}$ & 0.58 & 0.73 & 0.43 & 0.42 & 0.38 & 0.34 & 0.32 \\
\hline Post-orbital distance (Post-o-D) & $\mathrm{cm}$ & 1.00 & 1.22 & 0.68 & 0.64 & 0.70 & 0.57 & 0.43 \\
\hline Nostrils 1 interval (N1-I) & $\mathrm{cm}$ & 0.26 & 0.63 & 0.42 & 0.37 & 0.32 & 0.39 & 0.23 \\
\hline Nostrils 2 interval (N2-I) & $\mathrm{cm}$ & 0.21 & 0.56 & 0.36 & 0.34 & 0.30 & 0.34 & 0.20 \\
\hline Commissure interval (CI) & $\mathrm{cm}$ & 0.62 & 1.31 & 0.70 & 0.67 & 0.70 & 0.68 & 0.50 \\
\hline
\end{tabular}

a ratio between 28 and $32 \%$. Our results regarding HL-SL ratio, are ranged between $23.83 \%$ (the adult male captured at Mica) and $33.50 \%$ (the specimen caught at Țaga). The head length and standard length mean ratio is $28.96 \%$. Regarding the eye diameter (ED) and head length (HL) ratio, it must be placed within the $18.60 \%-31.00 \%$ interval. The mean value of this ratio, according to our results, is $19.16 \%$. The lowest value was obtained from the adult male specimen (Mica) $15.00 \%$, and the highest value was obtained from the smallest specimen from Sântioana (Fizeş River) $(23.52 \%)$. It is possible that along with body development and aging, the ratio between the eye diameter (ED)and head length (HL) might decrease. The proportion of $18.60 \%-31.00 \%$ presented by Bănărescu (1964), is referring to racer goby specimens caught in Razelm Lake, Călăraşi ponds and Colentina Catchment. Surely, the basic feed and the environment conditions from the native place of this species differ from those found in Transylvania, which is why the ED-
HL proportion has mean values that fall in those cited in the published literature just above the lower limit. A similar situation occurred in the case of the eye diameter (ED) and inter-orbital distance (I-oD) ratio. The mean value of this ratio is $173.51 \%$ (Bănărescu mentioning the 104.00 and $360 \%$ interval for this ratio). It is possible that changes might occur during the ontogenetic development, the lowest value being obtained from the adult male specimen (Mica-72.00\%), whereas the highest value was obtained from the smallest specimen, caught at Sântioana (280.00\%).

The caudal peduncle is short, as mentioned in the published literature, the caudal peduncle length (CpL) and standard length (SL) ratio of the captured specimens being equal to $11.60 \%$, with a low of $10.77 \%$ (the first specimen from Fizeșu Gherlii) and a high of $12.63 \%$ (the Țaga Lake specimen).The mean value of the pre-dorsal length 1 (Pr-dL1) and standard length(SL) ratio is $33.86 \%$, and the mean value of the ratio between the pre-dorsal length $2(\mathrm{Pr}-\mathrm{dL} 2)$ and the 
Tab. 3.Determined biometric values of the racer gobies (Babka gymnotrachelus) captured in the Someş river basin

\begin{tabular}{|c|c|c|c|c|c|c|c|c|}
\hline \multirow{2}{*}{ Character } & \multirow{2}{*}{ MU } & \multirow{2}{*}{ Țaga } & \multirow{2}{*}{ Mica } & \multicolumn{2}{|c|}{ Gherla } & \multicolumn{2}{|c|}{ Fizeșu Gherlii } & \multirow{2}{*}{-Sântioana } \\
\hline & & & & 1 & 2 & 1 & 2 & \\
\hline Pre-dorsal length 1 (Pr-dL1) & $\mathrm{cm}$ & 2.33 & 3.22 & 1.80 & 1.76 & 1.71 & 1.61 & 1.40 \\
\hline Post-dorsal length 1 (Po-dL1) & $\mathrm{cm}$ & 3.97 & 7.05 & 3.90 & 3.49 & 3.29 & 3.28 & 3.08 \\
\hline Pre-dorsal length 2 (Pr-dL2) & $\mathrm{cm}$ & 3.21 & 4.92 & 2.65 & 2.58 & 2.34 & 2.29 & 2.04 \\
\hline Post-dorsal length 2 (Po-dL2) & $\mathrm{cm}$ & 3.00 & 5.30 & 3.02 & 2.66 & 2.60 & 2.59 & 2.46 \\
\hline Pre-pectoral length (Pr-pL) & $\mathrm{cm}$ & 1.94 & 2.95 & 1.68 & 1.59 & 1.54 & 1.46 & 1.12 \\
\hline Post-pectoral length (Po-pL) & $\mathrm{cm}$ & 3.92 & 7.11 & 3.90 & 3.58 & 3.30 & 3.34 & 3.39 \\
\hline Pre-ventral length (Pr-vL) & $\mathrm{cm}$ & 1.85 & 2.88 & 1.69 & 1.56 & 1.46 & 1.50 & 1.39 \\
\hline Post-ventral length (Po-vL) & $\mathrm{cm}$ & 3.91 & 7.41 & 4.07 & 3.71 & 3.45 & 3.38 & 3.31 \\
\hline Pre-anal length (Pr-sL) & $\mathrm{cm}$ & 3.28 & 5.27 & 3.09 & 2.88 & 2.62 & 2.58 & 2.64 \\
\hline Post-anal length (Po-aL) & $\mathrm{cm}$ & 2.48 & 4.91 & 2.64 & 2.34 & 2.24 & 2.26 & 1.95 \\
\hline Dorsal1-pectoral length (D1-pL) & $\mathrm{cm}$ & 0.59 & 0.70 & 0.59 & 0.56 & 0.53 & 0.51 & 0.60 \\
\hline Dorsal2-pectoral length (D2-pL) & $\mathrm{cm}$ & 1.29 & 2.11 & 1.10 & 1.13 & 0.90 & 0.92 & 1.03 \\
\hline Dorsal1-ventral length (D1-vL) & $\mathrm{cm}$ & 1.18 & 1.88 & 1.16 & 1.02 & 0.94 & 1.00 & 1.03 \\
\hline Dorsal2-ventral length (D2-vL) & $\mathrm{cm}$ & 1.57 & 2.75 & 1.49 & 1.39 & 1.20 & 1.23 & 1.22 \\
\hline Dorsal1-anal length (D1-aL) & $\mathrm{cm}$ & 1.73 & 2.68 & 1.74 & 1.45 & 1.32 & 1.36 & 1.48 \\
\hline Dorsal2-anal length (D2-aL) & $\mathrm{cm}$ & 1.08 & 1.70 & 1.07 & 0.85 & 0.87 & 0.87 & 1.01 \\
\hline Dorsal1-Dorsal2 length (D1-D2) & $\mathrm{cm}$ & 1.02 & 1.75 & 0.89 & 0.78 & 0.70 & 0.77 & 0.63 \\
\hline Pectoral-Ventral length (P-V) & $\mathrm{cm}$ & 0.61 & 0.46 & 0.23 & 0.36 & 0.21 & 0.33 & 0.48 \\
\hline Pectoral-Anal length (P-A) & $\mathrm{cm}$ & 1.55 & 2.45 & 1.43 & 1.30 & 1.13 & 1.09 & 1.54 \\
\hline Ventral-Anal length (V-A) & $\mathrm{cm}$ & 1.39 & 2.58 & 1.41 & 1.35 & 1.16 & 1.14 & 1.38 \\
\hline Dorsal fin1 height (Df1H) & $\mathrm{cm}$ & 0.45 & 1.53 & 0.75 & 0.59 & 0.71 & 0.65 & 0.42 \\
\hline Dorsal fin2 height (Df2H) & $\mathrm{cm}$ & 0.65 & 2.15 & 0.97 & 0.84 & 0.87 & 0.76 & 0.62 \\
\hline Pectoral fin length (PfL) & $\mathrm{cm}$ & 0.67 & 2.25 & 1.08 & 1.06 & 1.03 & 0.99 & 0.83 \\
\hline Ventral fin length (VfL) & $\mathrm{cm}$ & 0.85 & 1.94 & 0.99 & 0.95 & 0.79 & 0.87 & 0.60 \\
\hline Anal fin length (AfL) & $\mathrm{cm}$ & 0.41 & 1.04 & 0.48 & 0.46 & 0.43 & 0.44 & 0.37 \\
\hline Caudal fin length (CfL) & $\mathrm{cm}$ & 1.10 & 1.65 & 1.07 & 1.10 & 1.00 & 1.01 & 0.84 \\
\hline
\end{tabular}

standard length (SL) is48.70\%. The mean ratio value between the pectoral fin length (PfL) and the standard length (SL) has the value of $18.99 \%$, the values being very close in the case of six specimens (18.69\%-22.34\%), excepting the Taga Lake specimen $(11.75 \%)$. In the latter case, an erosion of the pectoral fins is possible,leading to a low ratio value, under the interval between $20.00 \%$ and $26.10 \%$ specified in the published literature (Bănărescu, 1964).The literature mentions an interval between $16.00 \%$ and $22.00 \%$ for the ventral fin length (VfL) and standard length ratio (SL).The mean value obtained for this ratio is $16.70 \%$.

From a morphological point of view, the body is slightly laterally flattened, the recorded values of the maximum height $(\mathrm{H})$ for all the specimensbeing somewhat higher than the body depth (BD) values. The head of the racer goby is larger compared to other body sizes, the maximum height $(\mathrm{H})$ being usually recorded in the nape area. Regarding the head, the dorsal profile is convex, presenting a pronounced upward slope on the oral-aboral axis.The convexity is declining aboral from the eyes,and the profile becomes almost rectilinear from the nape in the caudal direction.

In the biometric practice, alongside with the phenotypic characters, distances between various anatomical components are studied topographically (in the case of fish these include the pre- and post- fins distances andthe distances between fins) as well as the length of the fins. These determinations can establish a basis for fish species 
Tab. 4.Meristic measurements determined from the racer goby (Babka gymnotrachelus)

\begin{tabular}{cccccccc}
\hline Nr. & Location & SML & D1 & D2 & P & V & A \\
\hline 1 & Taga (Țaga Mare lake) & 56 & VI & I 15 & 17 & 10 & I 12 \\
\hline 2 & Mica (Someș river) & 61 & VII & I 17 & 18 & 10 & I 15 \\
\hline 3 & Gherla 1 (Someș-Fizeș confluence) & 59 & VI & I 15 & 16 & 10 & I 15 \\
\hline 4 & Gherla 2 (Someș-Fizeș confluence) & 58 & VI & I 17 & 17 & 10 & I 14 \\
\hline 5 & Fizeșu Gherlii 1 (Fizeș river) & 62 & VI & I 16 & 17 & 10 & I 13 \\
\hline 6 & Fizeșu Gherlii 2 (Fizeş river) & 60 & VI & I 18 & 16 & 10 & I 15 \\
\hline 7 & Sântioana (Fizeș river) & 61 & VI & I 15 & 16 & 10 & I 12 \\
\hline \multicolumn{1}{l}{ Note: SML-scales on median line; D1-dorsal fin 1; D2-dorsal fin 2; P-pectoral fin; V-ventral fin; A-anal fin } & & &
\end{tabular}
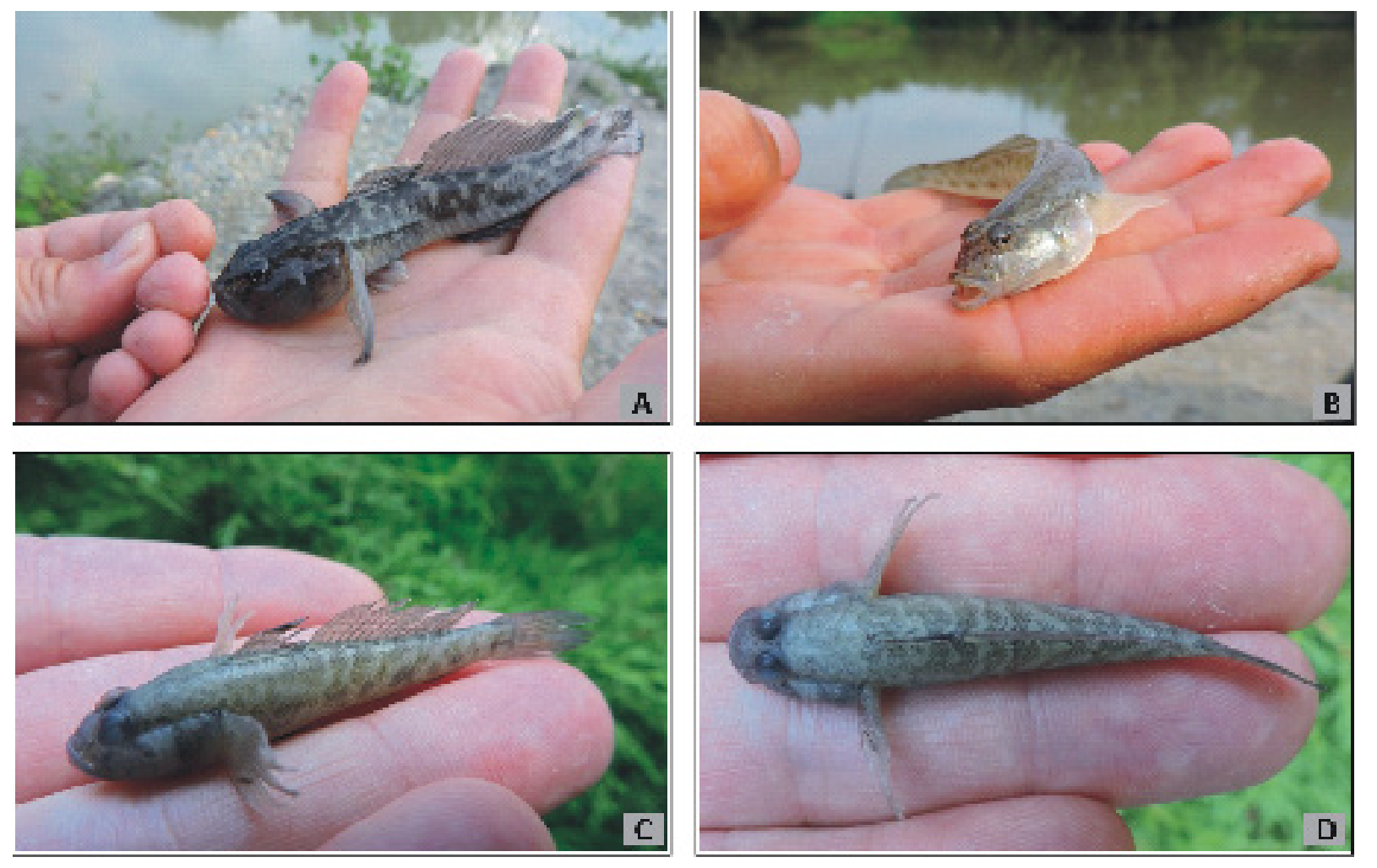

Fig. 3. Racer goby (Babka gymnotrachelus) specimens and pontian monkey goby (Neogobius fluviatilis) captured in the Someş Catchment: a - racer goby adult specimen (Someşul Mare River - Mica); b - pontian monkey goby specimen (Someșul Mare River - Mica); c, d - juvenile racer goby specimens (Fizeș River - Fizeșu Gherlii)

assessment keys, as is in the case of gobies, which morphologically greatly resemble one another, even though there are presently known over 170 species(Thacker and Roje, 2011).

On this line, we supplemented the previous data with the next determinations:pre-dorsal length 1 (Pr-dL1) [18], post-dorsal length 1 (PodL1) [19], pre-dorsal length 2 (Pr-dL2) [20], post-dorsal length 2 (Po-dL2) [21], pre-pectoral length (Pr-pL) [22], post-pectoral length (Po-pL) [23], pre-ventral length (Pr-vL) [24], post-ventral length (Po-vL) [25], pre-anal length (Pr-sL) [26], post-anal length (Po-aL) [27],dorsal1-pectoral length (D1-pL) [28], dorsal2-pectoral length (D2pL) [31],dorsal1-ventral length (D1-vL) [29], dorsal2-ventral length (D2-vL) [32], dorsal1-anal length (D1-aL) [30], dorsal2-anal length (D2aL) [33], dorsal1-dorsal2 length (D1-D2) [37], pectoral-ventral length (P-V) [34], pectoral-anal length (P-A) [35], ventral-anal length (V-A) [36], dorsal fin1 height (Df1H) [38], dorsal fin2 height (Df2H) [39], pectoral fin length (PfL) [40], ventral 
fin length (VfL) [41], anal fin length (AfL) [42] and caudal fin length (CfL) [43].

After analyzing all the biometric data, it was concluded that the fin sizes are larger (compared to other fish species) when reported to the body size. Besides the physiological aspects, including the adaptation to fresh water, this aspect helps the species in adapting to various environment circumstances, from shallow and stagnant waters to high water flow rivers. Moreover, the specimen caught fromSomeşul Mare River, downstream from the Mica Dam, was captured in an area with frequent water floods and furthermore, from the middle section of the stream riverbed.

The following meristic determinations (Tab. 4) were established for the racer gobies caught in the SomeșCatchment: SLL 56-62, D1 VI(VII), D2 I 15(16)-17(18), P 16-17(18), A I12(13)-(14)15. The recorded values fit the limits mentioned by the literature. Thus, Bănărescu (1964) states the next meristic measurements for this species: SLL 52-68(69), D1 VI(VII), D2 I(14)15-17(18), A I12-15(16). Haertl et al., (2012) presents similar values: SML $(59+3)-(65+4)$, D1 VI, D2 I17, A I15(14). All these confirm the fact that the species reported by us is in fact the racer goby.

One of the most efficient ways of identifying this species is by the presence of dark diagonal bands on the body sides. These are very visible on the juveniles and in the case of the mature specimen, even though it had a melanic colouring, the bands are still very noticeable (Fig. 3). Therefore the possibility of eroneous species identification is excluded, in the Somes Catchment being earlier identified another goby species (Pontian monkey goby - Neogobius Fluviatilis) (Cocan et al., 2014), with which the racer goby cannot be mistaken.

The racer goby cannot be mistaken for the pontian monkey goby, both because of its different coloring anddifferent conformation. Significant morphological differences can be observed, especially at head level, the pontian monkey goby having a more elongated profile. Regarding the buccal orifice, even though both species have a terminal disposition of the mouth, its orientation is much more slanted at the racer goby. Also, the racer goby has thicker lips, the upper one being slightly laterally widened and the pre-operculum bones are very developed.

\section{CONCLUSION}

The presence of a new gobiidae species, the racer goby (Babky gymnotrachelus) in the Somes Catchment is confirmed by the present study.It is the second goby species originating from the Ponto-Caspian area, the Black Sea (Romanian coastline) and south-eastern lakes, after the pontian monkey goby (Neogobius fluviatilis), that has been recorded in 2014.The presence of this species can be explained by its migration from the west towards the east, from the Danube, through Tisa, or by the fish material used for restocking Transylvanian fish farms, insufficiently sorted. According to the literature and published scientific papers, may occur in the future other gobies species, migrating from west to east.

The ecological impact of these species on native-endemic species from the Transylvanian freshwaters and also upon fish farms from this area remains to be evaluated, knowing the fact that the racer goby feed includes, among others, fish eggs, fish larvae and juveniles.

\section{Acknowledgments}

We wish to thank Dr. Ákos Harka (Hungarian Ichthyological Society - Hungary) for his help in identifying the species.

\section{REFERENCES}

1. A. Bij De Vaate AB, Jazdzewski K, Ketelaars HAM, Gollasch S, Van der Velda G (2002). Geographical patterns in range extension of Ponto-Caspian macroinvertebrate species in Europe. Can J Fish Aquat Sci, 59: 1159-1174.

2. Ahnelt H, Duchkowitsch M, Scattolin G, Zweimüller I, Weissenbacher A (2001). Neogobius gymnotrachelus (Kessler, 1857) (Teleostei: Gobiidae), die NackthalsGrundel in Österreich [The racer goby in Austria]. Österreichs Fischerei, 54: 262-266.

3. Bănărescu P (1964). Pisces - Osteichthyes. Fauna R. P. Romîne, Vol. 13. Ed. Academiei Republicii Populare Romîne, București, 959.

4. Borcherding J, Gertzen S, Staas S (2011). First record of Pontian Racer Goby, Babka gymnotrachelus (Gobiidae: Teleostei), in the River Rhine, Germany. J Appl Ichthyol 27: 1399-1400.

5. Cocan D, Mireșan V, Oțel V, Păpuc T, Lațiu C, Coșier V, Constantinescu R, Răducu C (2014). First Record of the Pontian Monkey Goby Neogobius fluviatilis (Pallas, 1814) in the Someș Rivern Transylvania - Romania. ProEnvironment, 7: 240 - 246.

6. Gollasch S, Galil BS, Cohen AN (2006). Bridging Divides: Maritime Canals as Invasion Corridors. Monographiae Biologicae, p. 74. 
7. GrabowskaJ, Grabowski M (2005). Diel-feeding activity in early summer of racer goby Neogobius gymnotrachelus (Gobiidae): a new invader in Baltic basin. J Appl Ichthyol 21: 282-286.

8. Grabowski M, Hupalo K, Bylak A, Kukula K, Grabowska J (2016). Double origin of the racer goby (Babka gymnotrachelus) in Poland revealed with mitochondrial marker. Possible implications for the species alien/native status. Journal of Limnology, 75: 101-108.

9. Guti C (2006). First record of Racer Goby Neogobius gymnotrachelus (PALLAS, 1811) in the Hungarian sector of the Danube. Opuscula Zoologica, 35: 83 - 84.

10. Haertl M, Cerwenka AF, Brandner J, Borcherding J, Geist J, Schliewen UK (2012). First record of Babka gymnotrachelus (Kessler, 1857) from Germany (Teleosttei, Gobiidae, Benthophilinae). Spixiana, 35: 155-159.

11. Hegediš A, Nikcevic M, Mickovic B, Jankovic D, Andjus RK (1991). Discovery of the goby Neogobius gymnotrachelus in Yugoslav fresh waters. Arhiv Bioloških Nauka, 43: 39-40.

12. Jermacz L, Kobak J, Dzierzynska A, Kakareko T (2015). The effect of flow on the competition between the alien racer goby and native European bullhead. Ecology of Freshwater Fish, 24: 467-477.

13. Jurajda P, Cerný J, Polacik M, Valová Z, Janác M, Blažek $\mathrm{R}$, Ondracková M (2005). The recent distribution and abundance of non-native Neogobius fishes in the Slovak section of the River Danube. J Appl Ichthyol 21: 319-323.

14. Kakareko T, Kobak J, Poznanska M, Jermacz L, Copp GH (2014). Underwater evaluation of habitat partitioning in a European river between a non-native invader, the racer goby and a threatened native fish, the European bullhead. Ecology of Freshwater Fish, 25: 60 - 71.

15. Kautman J (2001). The first occurrence of Neogobius gymnotrachelus in the Slovak Danube. Folia Zoologica, 50, 79-80.
16. Kostrzewa J, Grabowski M (2001). Racer (goad) goby, Neogobius gymnotrachelus (Kessler, 1857) (Gobiidae, Perciformes) - a new fish species in the Vistula River. Przeglad Zoologiczny, 45: 101 - 102.

17. Kostrzewa J, Grabowski M (2003). Opportunistic feeding strategy as a factor promoting the expansion of racer goby (Neogobius gymnotrachelus, Kessler, 1857) in the Vistula basin. Lauterbornia, 48: 91-100.

18. Miller JP, Ed. (2003). The Freshwater Fishes of Europe, Vol.8/I, Mugilidae, Atherinidae, Atherinopsidae, Blenniidae, Odontobutidae, Gobiidae 1. Aula-Verlag: 265 $-279$

19. Oțel V (2007). Atlasul peștilor din Rezervația Biosferei Delta Dunării. Ed. Centrul de Informare Tehnologică Delta Dunării.

20. Roche KF, Janač M, Jurajda P (2013). A review of Gobiid expansion along the Danube- Rhine corridor geopolitical change as a driver for invasion. Knowledge and Management of Aquatic Ecosystems. 411: 01.

21. Thacker CE, Roje DM (2011). Phylogeny of Gobiidae and identification of gobiid lineages. Systematics and Biodiversity 9(4): 329-347.

22. Vassilev MV, Trichkova TA, Ureche D, Stoica I, Battes K, Zivkov MT (2008). Distribution of Gobiid Species (Gobiidae, Pisces) in the Yantra River (Danube Basin, Bulgaria). Proceedings of the Anniversary Scientific Conference of Ecology, Plodviv, 2008, p. 163 - 172.

23. Zarev VY, Apostolu AI, Velkov BK, Vassilev MV (2013). Review of the Distribution of the Family Gobiidae (Pisces) in the Bulgarian Danube Tributaries. Ecologica Balkanica, 81-89.

24. Weiperth A, Staszny Á, Ferincz Á (2013). Occurrence and spread of non-native fish species in the Hungarian section of River Danube - A historical review. Pisces Hungarici, 7: 103-112. 